\title{
Multivalents resulting from monobrachial homologies within a hybrid zone in Dichroplus pratensis (Acrididae): meiotic orientation and segregation*
}

\author{
C. J. BIDAU \\ Departamento de Genética, Facultad de Ciencias Exactas, Químicas y Naturales, Universidad Nacional de Misiones, \\ Félix de Azara 174, 3300 Posadas, Misiones, Republica Argentina
}

\begin{abstract}
Natural populations of the South American grasshopper Dichroplus pratensis differ for seven polymorphic centric fusions involving the six longest telocentric autosomes of the karyotype (L1-L6). Hence, the same telocentric is involved in more than one fusion in different populations producing metacentrics with monobrachial homologies. The present study concerns the meiotic behaviour of quadrivalents and quinquivalents formed in natural hybrids that occur in two hybrid zones between chromosomal races with monobrachial homologies. The analysis revealed that: (a) non-alternate orientation of multivalents at Metaphase I (MI) was high, ranging from 18.5 to $64.2 \%$ of the cells in 18 hybrid males. Non-alternate Prometaphase (PMI) orientation was studied in six males (two of each type of hybrid) and in all cases values were higher than in MI, which suggests reorientation between PMI and MI. (b) All hybrids showed high frequencies of aneuploid and diploid second spermatocytes which are the result of abnormal segregation and lagging of chromosomes involved in multivalent formation. A highly significant correlation exists between the frequency of abnormal MI cells per male and abnormal second division spermatocytes. In most individuals, however, the frequency of abnormal second spermatocytes was lower than that of abnormal MI, which suggests further reorientation of multivalents towards alternate orientation at MI or spermatocyte selection between both meiotic divisions. (c) The hybrids have an increased production of macrospermatids.

The behaviour of the multivalents suggests that the inter-racial hybrids have their fertility moderately to severely reduced which infers the existence of post-mating reproductive isolation between races. This is discussed in relation to the maintenance and adaptive role of the fusion polymorphisms in nature.
\end{abstract}

Keywords: grasshopper, meiotic orientation, meiotic segregation, monobrachial homology, multivalent, reproductive isolation, Robertsonian translocation.

\section{Introduction}

Hybrid zones between parapatric populations are frequent and of interest to evolutionary biologists. Several models of speciation include them as a crucial stage (Barton \& Hewitt, 1981, 1985, 1989; Hewitt, $1985,1988)$. The forms involved may differ in morphological, ethological, allozymic or chromosomal features or a combination of them. In chromosomal hybrid zones, the nature of the chromosomal differ-

C. J. Bidau is a member of the Carrera del Investigador Cientifico y Tecnológico, Conicet.

*This paper is dedicated with affection to Professor Dr Rodolfo N. Panzarini. ences between the interacting populations will determine, along with other factors, the more or less negatively heterotic characteristics of the hybrids.

Chromosomal differences between hybridizing morphs are usually fixed as in the case of the hybrid zone between $\mathrm{XO} / \mathrm{XX}$ and neoXY/neoXX races of the grasshopper Podisma pedestris (Hewitt, 1975, 1985). Hence, hybrids are structural heterozygotes which may be negatively heterotic due to aberrant meiotic behaviour. Infertility will depend on the nature of the rearrangements as well as the meiotic behaviour of heterozygotes and the existence of compensatory mechanisms.

In the South American melanopline grasshopper, 
Dichroplus pratensis, different populations of its large distribution vary for a series of polymorphic and polytypic Robertsonian translocations between the six large (L) autosomes of the standard karyotype (Bidau, 1984, 1986, 1988, 1990; Bidau \& Mirol, 1988). Since the same telocentrics are involved in different arm combinations in different populations, metacentrics with monobrachial homologies are produced. Hybrids formed in contact zones between chromosomally divergent populations show multiples of higher order than trivalents during meiosis which are susceptible to non-alternate orientation and unbalanced segregation. With one exception, all populations sampled to date are polymorphic for the fusions. Thus the frequency of hybrids forming multivalents will depend on the frequencies of metacentrics with monobrachial homologies in each population.

One such zone of overlap has been found at Sierra de la Ventana (Buenos Aires province, Argentina) and is currently under study (Bidau, 1988). This paper describes the meiotic behaviour of several male structural hybrids which produce quadri- and quinquivalents of Robertsonian origin during meiosis. Orientation and segregation of multivalents have been the subjects of many experimental and theoretical investigations, although controversies still persist
(John, 1987; Sybenga \& Rickards, 1987). In addition, the role of monobrachial homologies in the establishment of postzygotic reproductive isolation and evolutionary divergence, is the subject of speculation, discussion and model-making (Capanna, 1982; Capanna et al., 1985; Baker \& Bickham, 1986; Searle, 1986a, 1988; Sites \& Moritz, 1987; Bidau, 1988, 1990; Redi \& Capanna, 1988). The results presented in this paper are discussed in relation to the present knowledge of multivalent behaviour. The implications of this behaviour for fertility and chromosome evolution in Dichroplus pratensis are considered. Although the investigation is not directly concerned with ultimate speciation but rather with a chromosomal system that would allow neighbouring conspecific populations to maintain their identity. The data are discussed in relation to current models of chromosomal speciation as the situation uncovered in this species could well represent an intermediate stage in the divergence of populations eventually leading to more complete separation and specification.

\section{Materials and methods}

This study is based on 17 male hybrids collected in 1983 and 1986 from several populations within a

Table 1 Origin and chromosome constitution of the hybrids studied in this paper

\begin{tabular}{|c|c|c|c|}
\hline $\begin{array}{l}\text { Male code } \\
\text { number }\end{array}$ & Locality* & $\begin{array}{l}\text { Date of } \\
\text { collection }\end{array}$ & $\begin{array}{l}\text { Chromosome } \\
\text { constitution } \dagger\end{array}$ \\
\hline $83357(1)$ & $\mathrm{Km} 784$, Natl. route 3 & $2 / 83$ & '561', Het $3 / 4$ \\
\hline $\begin{array}{l}83376(2) \\
83378(3) \\
83391(4) \\
83398(5) \\
83413(6)\end{array}$ & $\begin{array}{l}\text { Natl. route } 72,3 \mathrm{~km} \text { north of } \\
\text { Sierra de la Ventana }\end{array}$ & $\begin{array}{l}2 / 83 \\
2 / 83 \\
2 / 83 \\
2 / 83 \\
2 / 83\end{array}$ & $\begin{array}{l}\text { ‘561', Hom } 3 / 4 \\
\text { ‘561', Hom } 3 / 4 \\
\text { ‘561', Hom } 3 / 4 \\
\text { ‘561', Hom } 3 / 4 \\
\text { '561', Het } 3 / 4\end{array}$ \\
\hline $\begin{array}{l}86108(7) \\
86111(8) \\
86117(9)\end{array}$ & $\begin{array}{l}\text { Villa Ventana, } 2 \mathrm{~km} \text { south of } \\
\text { Natl. route } 72\end{array}$ & $\begin{array}{l}1 / 86 \\
1 / 86 \\
1 / 86\end{array}$ & $\begin{array}{l}\text { ‘561', St } 3 / 4 \\
\text { ‘561', Hom } 3 / 4 \\
\text { ‘561', Hom } 3 / 4\end{array}$ \\
\hline $\begin{array}{l}86210(10) \\
86211(11) \\
86214(12)\end{array}$ & El Atravesado & $\begin{array}{l}1 / 86 \\
1 / 86 \\
1 / 86\end{array}$ & $\begin{array}{l}\text { '561', Hom } 3 / 4 \\
\text { ‘561', Hom } 3 / 4 \\
\text { ‘561', Hom } 3 / 4\end{array}$ \\
\hline $\begin{array}{l}86295(13) \\
86308(14) \\
83408(15) \\
86307(16) \\
83403(17)\end{array}$ & $\begin{array}{l}\text { Natl. route } 72,3 \mathrm{~km} \text { north of } \\
\text { Sierra de la Ventana }\end{array}$ & $\begin{array}{l}1 / 86 \\
1 / 86 \\
2 / 83 \\
1 / 86 \\
2 / 83\end{array}$ & $\begin{array}{l}\text { ‘561', Hom } 3 / 4 \\
\text { ‘ } 561 \text { ', Het } 3 / 4 \\
\text { ‘ } 612 \text { ', Het } 3 / 4 \\
\text { ‘ } 612 \text { ', Hom } 3 / 4+\text { B } \\
\text { ' } 5612 \text { ', Het } 3 / 4\end{array}$ \\
\hline $86195(18)$ & El Atravesado & $1 / 86$ & '5612', Hom 3/4 \\
\hline
\end{tabular}

*All localities belong to Buenos Aires province.

†'561': hybrid forming a 5-5.6-6.1-1 quadrivalent; '612': 6-6.1-1.2-2 quadri-

valent; '5612': 5-5.6-6.1-1.2-2 quinquivalent. 
hybrid zone at Sierra de la Ventana, and a single hybrid recovered in 1983 from a population in the Southern Buenos Aires province (National Route 3, $784 \mathrm{~km}$ ), which presumably belongs to another hybrid zone. Table 1 summarizes the chromosome constitution of the hybrids as well as the localities of origin and collection dates. In all cases testes were dissected out in the field and fixed in 3:1 methanol:acetic acid. Observations were performed on lacto-propionic orcein squashes.

\section{Results}

\section{The hybrids and their origins}

The all-telocentric $2 n=19(\mathrm{XO}){ }^{\circ}$ standard karyotype of $D$. pratensis includes six pairs of large $(\mathrm{L})$ autosomes (L1-L6) involved in Robertsonian translocations in different populations (Bidau, 1988, 1990; Bidau \& Mirol, 1988). At Sierra de la Ventana, the ranges of two races make contact to produce a large zone of hybridization (Mirol et al., 1988). The 'Northern' race is polymorphic for fusions $1 / 6$ and $3 / 4$; the 'Southern' race is polymorphic for fusions $1 / 2,3 / 4$ and $5 / 6$. Within the hybrid zone, many populations comprise individuals that can be ascribed to one or other race, others that may belong to either one (i.e. standards or those with the $3 / 4$ fusion only) and hybrids. The latter consist of three types according to the monobranchial homologies involved: (i) - '561' type in addition to the chromosomes shared by both races they have two metacentrics, 1.6 and 5.6 and two telecentrics, 1 and 5, which engage in quadrivalent $(5-5.6-6.1-1)$ formation at meiosis]; (ii) ' 612 ' type (6-6.2-1.2-2 quadrivalent) and (iii) '5612' type (5-5.6-6.1-1.2-2 quinquivalent) (Figs 1 and 2). The hybrid from $784 \mathrm{~km}$ is of the ' 561 ' type.

\section{Chromosome pairing in hybrids}

Between 20 and 100 late pachytene nuclei were studied in all hybrids. No case of pairing failure was detected at this stage and almost certainly the maximum multiple formation is unhindered and complete. Late pachytene configurations of multivalents are shown in Fig. 2.

\section{Orientation of multivalents at first meiotic division}

Chain multivalents of Robertsonian origin have only one mode of orientation that ensures balanced segregation in principle: i.e. in which adjacent centromeres are oriented to opposite spindle poles. For chain trivalents,
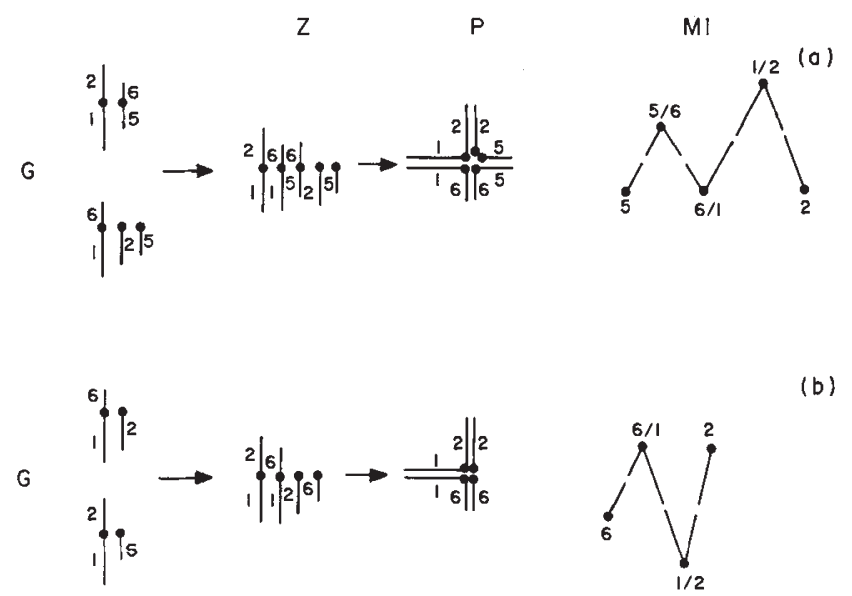

(b)

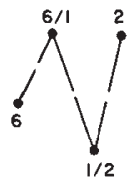

(c)
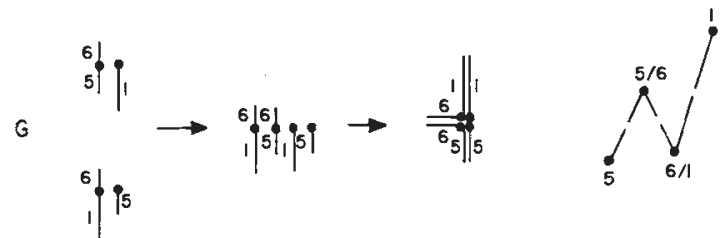

Fig. 1 The origin of the three types of multivalents of hybrids between races of Dichroplus pratensis with monobrachial homologies. (a) '5612', (b) '612', (c) '561'. $\mathrm{G}=$ parental gametes (only the relevant chromosomes are shown); $\mathrm{Z}=$ zygotic complement; $\mathrm{P}=$ pachytene pairing; $\mathrm{MI}=$ alternate orientation of multiple.
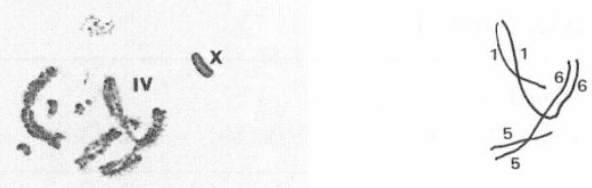

(a)
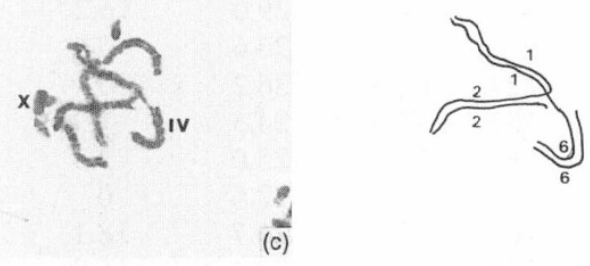

(d)
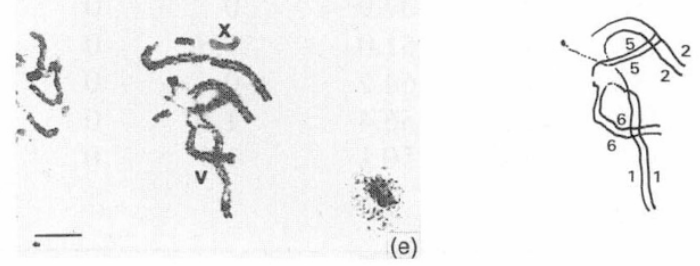

(e)

Fig. 2 Late pachytene pairing of multivalents in D. pratensis hybrids. (a, b) '561' quadrivalent, (c, d) '612' quadrivalent, $(\mathrm{e}, \mathrm{f})$ ' 5612 ' quinquivalent. $\mathrm{Bar}=10 \mu \mathrm{m}$. 
this configuration has been variously termed V-orientation (Rickards, 1983), convergent (John \& Lewis, 1963; Bidau \& Mirol, 1988), disjunctional (John, 1983) and alternate (Rickards, 1983; Sybenga \& Rickards, 1987). For clarity, the more usual term 'alternate' will be used in this paper to describe chain multivalents disjunctionally oriented, and 'non-alternate' for all those orientations that do not ensure balanced segregation.

Orientation at MI. The frequency of alternate orientation was determined in MI cells for all hybrids (Table 2). A cell was considered to be at MI when the $X$ chromosome was negatively heteropycnotic and located at one of the spindle poles (or at least with its centromere facing a pole) and the remaining configurations not involved in the multiple (mostly bivalents but also trivalents; see Table 1) were at the equator with the centromeres facing opposite poles. Cells in polar view were not included in the analysis. Tables 2 and 3 show the frequencies of different orientations of multivalents. In Table 2 all non-alternate orientations were pooled. Table 3 shows the discrimination of the several types of non-alternate orientation and other configurations. Alternate configurations are depicted in Figs 1 and 3. Several non-alternate configurations occur in quadrivalents but two were predominant: one in which the centromeres of the telocentrics faced one pole while those of the metacentrics faced the opposite (Fig. 4a; Table 3); the other, where both telocentrics were oriented to the same pole and one metacentric centromere faced one pole while the other was stretched (Fig. 4b-d; Table 3).

The more frequent types of non-alternate orientation of the quinquivalent are shown in Fig. $4 \mathrm{~g}-\mathrm{i}$ and Table 3. At variance with the situation of the quadrivalents, and quinquivalent showed little tendency for the orientation in which the centromeres of the telocentrics face one pole while the metacentrics are oriented to the opposite (Table 3).

Cells that show chiasma failure (leading to multivalent disruption) were scored separately (Fig. 4e; Tables 2 and 3 ) as well as those showing spontaneous chromosome breakage (Table 2). Frequencies of abnormal MI cells ranged between 18.5 and $64.2 \%$, the main component being non-alternate orientation

Table 2 Non-alternate orientation, univalence, spontaneous chromosome breakage and segregation of Robertsonian multiples of Dichroplus pratensis

\begin{tabular}{|c|c|c|c|c|c|c|c|c|c|c|c|}
\hline \multirow[b]{2}{*}{$\begin{array}{l}\text { Hybrid } \\
\text { number }\end{array}$} & \multicolumn{5}{|c|}{ Metaphase I } & \multicolumn{4}{|c|}{ Metaphase II } & \multicolumn{2}{|l|}{ Totals } \\
\hline & $\begin{array}{l}\text { Total } \\
\text { cells }\end{array}$ & $\mathrm{A}(\%)$ & NA $(\%)$ & $\mathrm{CF}(\%)$ & $\mathrm{Sb}(\%)$ & $\begin{array}{l}\text { Total } \\
\text { cells }\end{array}$ & $\mathrm{H}(\%)$ & $\operatorname{An}(\%)$ & $\mathrm{D}-\mathrm{P}(\%)$ & $\begin{array}{l}\mathrm{Ab}(\%) \\
\mathrm{MI}\end{array}$ & $\begin{array}{l}\mathrm{Ab}(\%) \\
\mathrm{MII}\end{array}$ \\
\hline 1 & 195 & 81.5 & 18.5 & 0 & 0 & 42 & 83.3 & 16.7 & 0 & 18.5 & 16.7 \\
\hline 2 & 105 & 63.8 & 32.4 & 3.8 & 0 & 0 & 87.5 & 12.5 & 0 & 36.2 & 12.5 \\
\hline 3 & 60 & 63.3 & 35.0 & 1.7 & 0 & 9 & 66.7 & 33.3 & 0 & 36.7 & 33.3 \\
\hline 4 & 307 & 44.0 & 48.5 & 7.5 & 0 & 60 & 69.6 & 28.6 & 1.8 & 56.0 & 30.4 \\
\hline 5 & 321 & 54.8 & 29.0 & 16.2 & 0 & 22 & 54.5 & 27.3 & 18.2 & 45.2 & 45.5 \\
\hline 6 & 246 & 75.6 & 23.6 & 0.8 & 0 & 41 & 65.9 & 29.3 & 4.8 & 24.4 & 34.1 \\
\hline 7 & 224 & 63.8 & 36.2 & 0 & 0 & 28 & 64.3 & 35.7 & 0 & 36.2 & 35.7 \\
\hline 8 & 107 & 72.9 & 24.3 & 1.9 & 0.9 & 247 & 74.5 & 24.3 & 1.2 & 27.1 & 25.5 \\
\hline 9 & 88 & 72.7 & 25.0 & 2.3 & 0 & 184 & 81.5 & 15.2 & 3.3 & 27.3 & 18.5 \\
\hline 10 & 234 & 77.4 & 22.6 & 0 & 0 & 59 & 91.5 & 8.5 & 0 & 22.6 & 8.5 \\
\hline 11 & 105 & 55.2 & 26.7 & 18.1 & 0 & 39 & 69.2 & 25.6 & 5.2 & 43.1 & 30.8 \\
\hline 12 & 361 & 59.5 & 24.4 & 15.8 & 0.3 & 139 & 71.2 & 12.2 & 16.6 & 40.5 & 28.8 \\
\hline 13 & 97 & 70.1 & 29.9 & 0 & 0 & 87 & 81.6 & 9.2 & 9.2 & 29.9 & 18.4 \\
\hline 14 & 58 & 62.1 & 37.9 & 0 & 0 & 50 & 70.0 & 16.0 & 14.0 & 37.9 & 30.0 \\
\hline 15 & 196 & 47.4 & 51.0 & 1.6 & 0 & 53 & 52.8 & 32.1 & 15.1 & 52.6 & 47.2 \\
\hline 16 & 53 & 35.8 & 64.2 & 0 & 0 & 21 & 42.8 & 42.8 & 14.3 & 64.2 & 57.1 \\
\hline 17 & 287 & 42.2 & 56.4 & 1.4 & 0 & 63 & 57.1 & 36.5 & 6.4 & 57.8 & 42.9 \\
\hline 18 & 413 & 48.4 & 50.1 & 1.5 & 0 & 157 & 63.0 & 28.7 & 8.3 & 50.7 & 37.0 \\
\hline Total & 3457 & & & & & 1313 & & & & & \\
\hline
\end{tabular}

The chromosome constitution of the hybrids is described in Table 1. A= alternate; $\mathrm{NA}=$ non-alternate; $\mathrm{CF}=$ chiasma failure; $\mathrm{SB}=$ spontaneous chromosome breakage; $\mathrm{H}=$ haploid second spermatocytes; $\mathrm{An}=$ aneuploid second spermatocytes; $\mathrm{D}-\mathrm{P}=$ diploid and polyploid second spermatocytes; $\mathrm{Ab} \mathrm{MI}, \mathrm{Ab} \mathrm{MII}=$ abnormal first and second spermatocytes. 
(Tables 2 and 3). Chiasma failure was exceptionally high in four males, and spontaneous breakage was very rare $(2$ cells $/ 3000)$ (Table 2$)$.

Prometaphase I-metaphase I comparisons. The frequency of alternate orientation at PMI was determined in six males (Table 4). This was done in order to calculate the amount of reorientation that might occur between PMI and MI. Prometaphase I is not an easy stage to define nor is the transition between PMI were those that were not diakinetic (as defined by John \& Lewis, 1965 for male grasshopper meiosis) but also did
Table 4 Frequencies of alternate orientation at prometaphase I in six hybrids of Dichroplus pratensis

\begin{tabular}{lllll}
\hline $\begin{array}{l}\text { Hybrid } \\
\text { number }\end{array}$ & $\begin{array}{l}\text { Hybrid } \\
\text { type }\end{array}$ & $\begin{array}{l}\text { Number PMI } \\
\text { cells }\end{array}$ & $\begin{array}{l}\text { Alternate } \\
(\%)\end{array}$ & $\begin{array}{l}\text { Alternate } \\
\text { at MI (\%) }\end{array}$ \\
\hline 83357 & '561' & 70 & 57.0 & 81.5 \\
83398 & '561' & 39 & 31.0 & 54.8 \\
83408 & '612' & 33 & 24.2 & 47.4 \\
86307 & '612' & 23 & 26.1 & 35.8 \\
83403 & '5612' & 25 & 24.0 & 42.2 \\
86195 & '5612' & 48 & 25.0 & 48.4 \\
\hline
\end{tabular}

Table 3 Metaphase I configurations of multivalents in ' 561 ' and ' 5612 ' hybrids of Dichroplus pratensis

\begin{tabular}{|c|c|c|c|c|c|c|c|c|c|c|c|c|}
\hline \multirow[b]{3}{*}{$\begin{array}{l}\text { Male number } \\
\text { configuration }\end{array}$} & \multicolumn{12}{|c|}{$\%$ Different MI orientation types } \\
\hline & \multicolumn{8}{|c|}{ '561' Multivalent } & \multirow[b]{2}{*}{$\begin{array}{l}\text { Male number } \\
\text { configuration }\end{array}$} & \multicolumn{3}{|c|}{ '5612' Multivalent } \\
\hline & 7 & 8 & 9 & 10 & 11 & 12 & 13 & $\begin{array}{l}\text { Total } \\
\text { cells }(\%)\end{array}$ & & 17 & 18 & $\begin{array}{l}\text { Total } \\
\text { cells }(\%)\end{array}$ \\
\hline ' & 63.8 & 72.9 & 72.7 & 77.4 & 55.2 & 59.5 & 70.1 & $\begin{array}{l}802 \\
(66.0)\end{array}$ & & 42.2 & 48.4 & $\begin{array}{l}321 \\
(45.9)\end{array}$ \\
\hline 17 & 18.8 & 13.1 & 12.5 & 12.7 & 11.4 & 12.9 & 14.4 & $\begin{array}{l}170 \\
(14.0)\end{array}$ & & 5.6 & 4.3 & $\begin{array}{l}34 \\
(4.9)\end{array}$ \\
\hline 1 & 13.2 & 6.5 & 9.1 & 5.5 & 6.7 & 6.5 & 9.3 & $\begin{array}{l}98 \\
(8.1)\end{array}$ & & 6.9 & 8.8 & $\begin{array}{l}56 \\
(8.0)\end{array}$ \\
\hline 1 & 3.0 & 2.8 & 2.3 & 2.2 & 6.7 & 3.0 & 6.2 & $\begin{array}{l}41 \\
(3.4)\end{array}$ & & 12.6 & 10.4 & $\begin{array}{l}79 \\
(11.3)\end{array}$ \\
\hline Other & 1.2 & 2.8 & 1.1 & 2.2 & 1.9 & 2.3 & 0.0 & $\begin{array}{l}25 \\
(2.1)\end{array}$ & & 8.4 & 8.2 & $\begin{array}{c}58 \\
(8.3)\end{array}$ \\
\hline $\mathrm{III}+\mathrm{I}$ & 0.0 & 0.0 & $2.3^{*}$ & 0.0 & $15.2^{*}$ & $15.8^{*}$ & 0.0 & $\begin{array}{l}75 \\
(6.3)\end{array}$ & & 17.3 & 14.1 & $\begin{array}{l}108 \\
(15.4)\end{array}$ \\
\hline $\mathrm{II}+\mathrm{II}$ & 0.0 & 1.9 & 0.0 & 0.0 & 1.9 & 0.0 & 0.0 & $\begin{array}{l}4 \\
(0.3)\end{array}$ & & 0.0 & 0.5 & $\begin{array}{l}2 \\
(0.3)\end{array}$ \\
\hline $\mathrm{II}+\mathrm{I}+\mathrm{I}$ & 0.0 & 0.0 & 0.0 & 0.0 & 1.0 & 0.0 & 0.0 & 1 & 1 & 1.4 & 1.0 & $(1.1)$ \\
\hline \multirow[t]{4}{*}{ Number of cells } & 224 & 107 & 88 & 234 & 105 & 361 & 97 & 1216 & Other & 4.2 & 2.9 & $\begin{array}{l}24 \\
(3.4)\end{array}$ \\
\hline & & & & & & & & & $\mathrm{IV}+\mathrm{I}$ & 0.0 & 1.2 & $\begin{array}{l}5 \\
(0.7)\end{array}$ \\
\hline & & & & & & & & & $\mathrm{II}+\mathrm{II}+\mathrm{I}$ & 1.4 & 0.3 & $\begin{array}{l}5 \\
(0.7)\end{array}$ \\
\hline & & & & & & & & & Number of cells & 287 & 413 & 700 \\
\hline
\end{tabular}

*The univalent is almost invariably L5. For the ' 561 ' quadrivalent, the third type of orientation is a pool of the orientations in which the 5.6 or the 1.6 centromeres are stretched. The other category includes those orientations which could not be classified with certainty. Only those configurations observed were considered. 


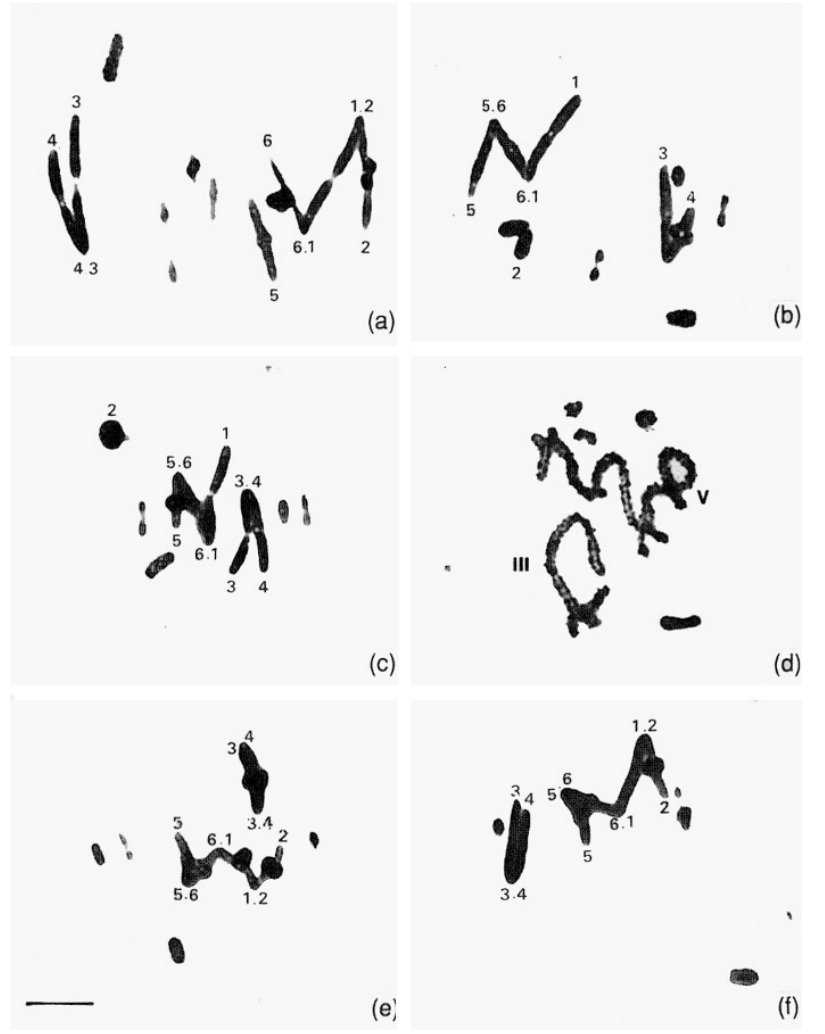

Fig. 3 Meoitic configurations of multivalents in $D$. pratensis hybrids. All MI configurations (a-c, e-f) show alternate orientation of the multiples. (a) ' 612 ', (b, c) ' 561 ',

(d) diplotene configuration of ' 5612 ' quinquivalent (V), (e, f) '5612'. Bar $=10 \mu \mathrm{m}$.

not meet the conditions for being a MI cell as defined above. Hence PMI cells were considered to be those in which autosomes were condensed, as in MI (or nearly so), but the $\mathrm{X}$ was isopycnotic and not at a pole, and one or more meiotic configurations other than the multivalent under study as out of the equatorial region.

Frequencies of alternate orientation of the chains are plotted in Fig. 5 by considering a hypothetical initial frequency (see Sybenga, 1975). It is evident from the graphs that there is an increase in the alternate configuration as $\mathrm{MI}$ is approached.

\section{Chiasma frequency and localization related to orientation}

Factors that determine the orientation of Robertsonian trivalents are chiasma frequency and position: proximal, and to a lesser degree, interstitial chiasmata, tend to make alternate orientation difficult (Bidau \& Mirol, 1988). This is also true of higher order Robertsonian multiples. A summary of the results of an analysis of chiasma frequencies and distributions in the multiples studied in this paper is presented in Table 5. In 13 out of 18 cases, the total chiasma frequency was higher in the abnormally oriented multivalents and, more relevant, the frequency of proximal and interstitial chiasmata was significantly higher in non-alternate multivalents in the majority of individuals studied. Multivalents with different numbers and positions of chiasmata are shown in Figs 3 and 4.

\section{Segregation}

Non-alternate orientation of the Robertsonian multiples at MI should lead to unbalanced segregation and aneuploid gametes. To test this prediction, Anaphase I (AI), MII and AII cells were pooled and classified as euploid or aneuploid. Aneuploidy at second division (Fig. 6c) can result from unbalanced segregation (Fig. $5 \mathrm{c}$ ) or from lagging of one or more chromosomes of the multivalent (Fig. 5d-f). Figure 5a and $b$ shows two instances of balanced segregation.

As reported earlier (Bidau \& Confalonieri, 1988), the lagging of chromosomes at AI may result in blocking or distortion of cytokinesis leading to diploid (unreduced) second division cells (Fig. 6a and b). Diploid (and polyploid) MII/AII cells were also scored. In Table 2 the total frequency of abnormal second division cells was calculated for each individual. Note that there is a significant correlation between the total frequency of abnormal MI cells and the total frequency of abnormal second spermatocytes (Fig. 7). It should be noted that, in the hybrids, the frequency of abnormal second spermatocytes is almost always lower than that of abnormal MI cells (Table 2), the only exceptions being males 83398 and 83413 .

Although a positive correlation exists between frequencies of univalence at MI and diploid/polyploid second spermatocytes (Fig. 8), it is not significant.

\section{Macrospermatid production}

As diploid (and polyploid) second spermatocytes produce macrospermatids, the frequency of the latter in hybrids was compared to that of randomly chosen nonhybrid males of the same population regardless of karyotype. Macrospermatids are shown in Fig. 5g. The results shown in Table 6 indicate that hybrids produce macrospermatids in quantities significantly higher than non-hybrid males.

\section{Discussion}

Dichroplus pratensis offers the opportunity to study two problems of interest to cytogenetics: the role of monobrachial homologies in post-zygotic reproductive 


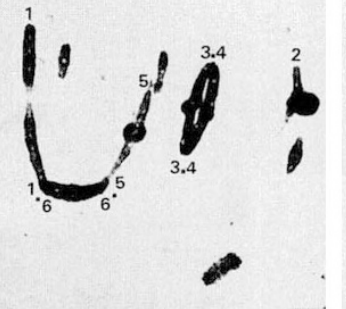

(a)

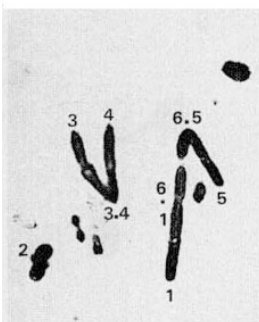

(d)
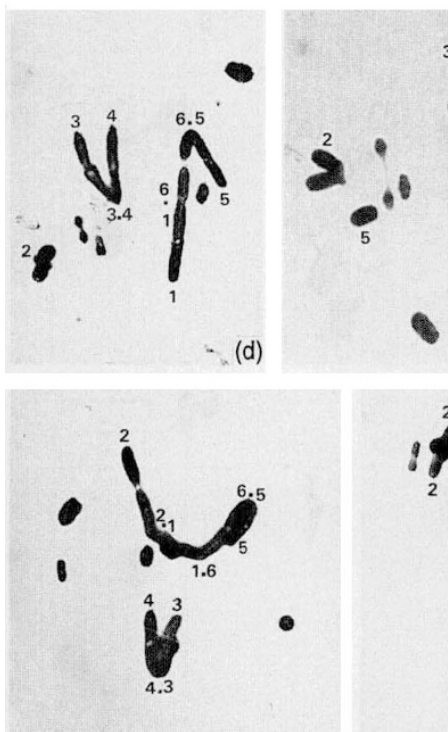
(g-i) non-altermater quinquivalent. Bar $=10 \mu \mathrm{m}$.

Fig. 4 Abnormal behaviour of multivariants at MI. (a-d) Non-alternate orientation of ' 561 ' quadrivalent, (e) chiasma failure in chromosome 5 of a ' 561 ' quadrivalent, (f) spontaneous breakage in '561' quadrivalent (arrow),
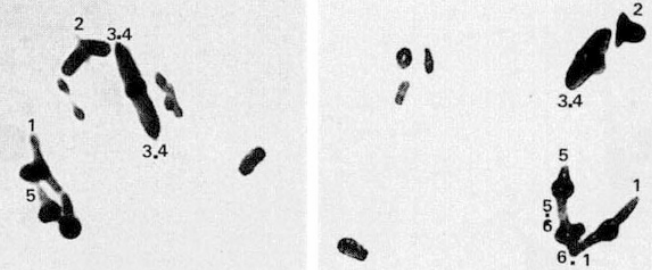

(b)

(c)

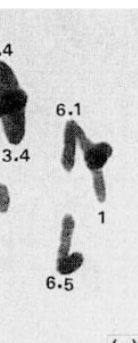

(e)
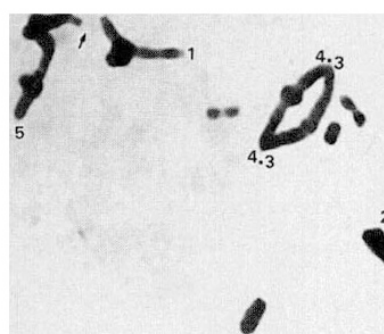

(f)

Table 5 Analysis of chiasma frequency and distribution in alternately and non-alternately oriented multivalents in 18 natural hybrids of Dichroplus pratensis

\begin{tabular}{lllllllllll}
\hline $\begin{array}{l}\text { Hybrid } \\
\text { number }\end{array}$ & $\bar{X}_{\mathrm{t}} \mathrm{A}$ & $\bar{X}_{\mathrm{t}} \mathrm{NA}$ & $\begin{array}{l}t \\
\text { value }\end{array}$ & \multicolumn{1}{c}{$\mathrm{df}$} & $\begin{array}{l}P \\
\text { value }\end{array}$ & $\bar{X}_{\mathrm{I}+\mathrm{P}} \mathrm{A}$ & $\bar{X}_{\mathrm{I}+\mathrm{P}} \mathrm{NA}$ & $\begin{array}{l}t \\
\text { value }\end{array}$ & \multicolumn{2}{c}{$\begin{array}{l}P \\
\text { df }\end{array}$} \\
\hline 86108 & 3.00 & 3.15 & 1.78 & 38 & $0.1-0.05$ & 0.70 & 1.30 & 1.95 & 38 & $0.1-0.05$ \\
83357 & 3.00 & 3.00 & 0.00 & 38 & & 0.00 & 0.00 & & & \\
83413 & 3.09 & 3.41 & 2.03 & 62 & $0.05-0.01$ & 0.21 & 0.53 & 1.86 & 62 & $0.1-0.05$ \\
86308 & 3.03 & 3.14 & 1.03 & 56 & $0.50-0.30$ & 0.67 & 1.46 & 3.52 & 56 & $<0.001$ \\
83376 & 3.00 & 3.25 & 1.42 & 14 & $0.30-0.10$ & 1.63 & 2.00 & 1.08 & 14 & $0.30-0.10$ \\
83378 & 3.24 & 3.00 & 2.15 & 25 & $0.05-0.01$ & 0.29 & 0.50 & 0.78 & 25 & $0.50-0.30$ \\
83391 & 3.70 & 3.95 & 0.91 & 38 & $0.50-0.30$ & 1.70 & 1.80 & 0.03 & 38 & $>0.90$ \\
83398 & 3.24 & 3.27 & 0.23 & 66 & $0.90-0.70$ & 1.20 & 0.92 & 1.60 & 66 & $0.30-0.10$ \\
86111 & 3.05 & 3.20 & 1.43 & 38 & $0.30-0.10$ & 0.55 & 1.20 & 2.42 & 38 & $0.05-0.01$ \\
86117 & 3.10 & 3.05 & 0.53 & 37 & $0.70-0.50$ & 0.65 & 1.37 & 2.86 & 37 & $0.01-0.001$ \\
86210 & 3.00 & 3.00 & 0.00 & 38 & & 0.60 & 0.90 & 1.03 & 38 & $0.50-0.30$ \\
86211 & 3.00 & 3.00 & 0.00 & 38 & & 0.65 & 0.80 & 0.64 & 38 & $0.70-0.50$ \\
86214 & 3.02 & 3.08 & 1.25 & 147 & $0.30-0.10$ & 0.47 & 0.83 & 2.63 & 147 & $0.01-0.001$ \\
86295 & 3.03 & 3.11 & 1.23 & 95 & $0.30-0.10$ & 0.65 & 1.21 & 3.69 & 95 & $<0.001$ \\
83408 & 3.29 & 3.41 & 1.43 & 112 & $0.30-0.10$ & 1.14 & 1.31 & 1.67 & 112 & $0.10-0.05$ \\
86307 & 3.11 & 3.71 & 4.47 & 51 & 0.001 & 1.90 & 2.56 & 3.24 & 51 & $0.01-0.001$ \\
83403 & 4.31 & 4.45 & 1.19 & 86 & $0.30-0.10$ & 1.39 & 1.82 & 2.37 & 86 & $0.05-0.01$ \\
86195 & 4.15 & 4.30 & 0.26 & 38 & $0.90-0.70$ & 0.80 & 1.80 & 2.78 & 38 & $0.01-0.001$ \\
\hline
\end{tabular}

$\bar{X}_{\mathrm{t}} \mathrm{A}, \bar{X}_{\mathrm{t}} \mathrm{NA}=$ total chiasma frequency of alternately and non-alternately oriented multivalents.

$\bar{X}_{\mathrm{I}+\mathrm{P}} \mathrm{A}, \bar{X}_{\mathrm{I}+\mathrm{P}} \mathrm{NA}=$ interstitial + proximal chiasma frequency of alternately and non-alternately oriented multivalents. 

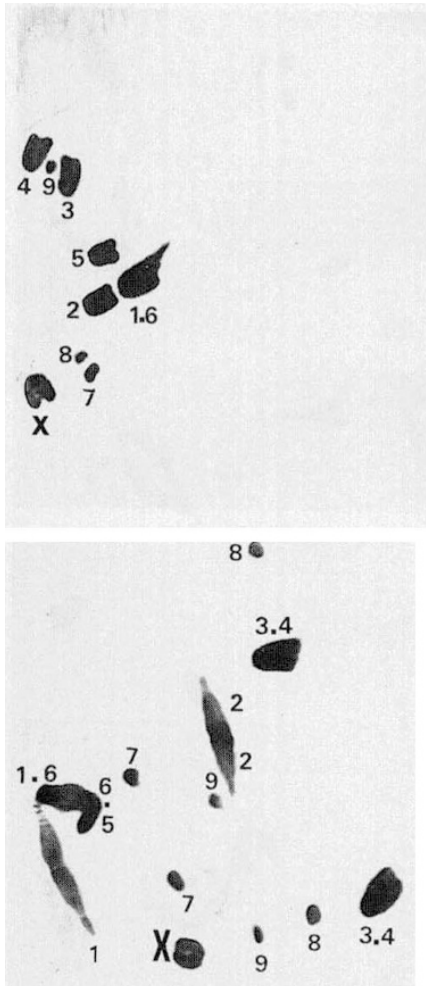

(c)
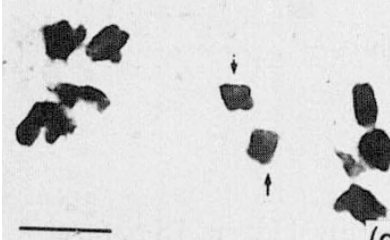

(d)

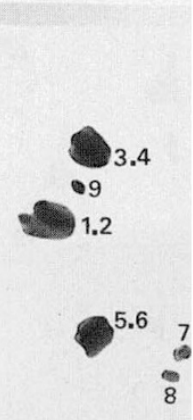

(a)
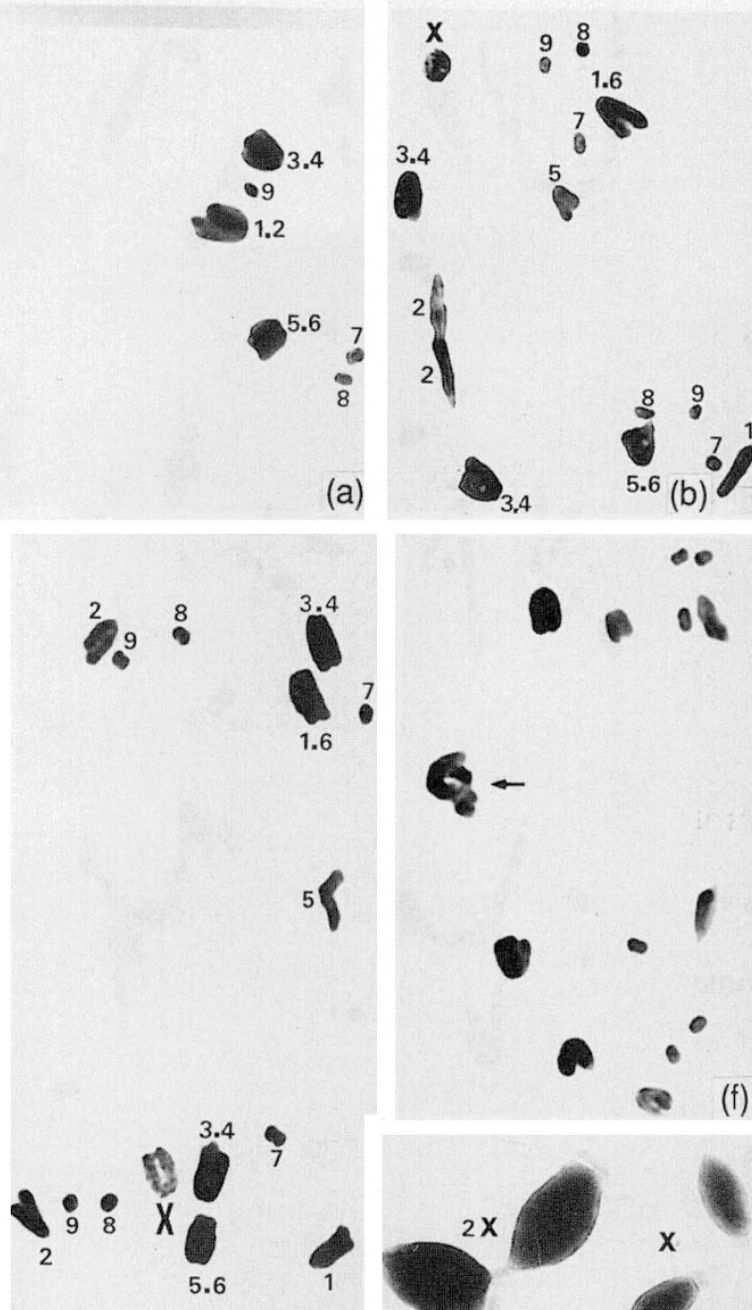
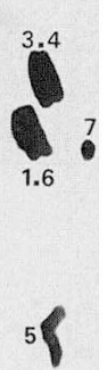

(e)
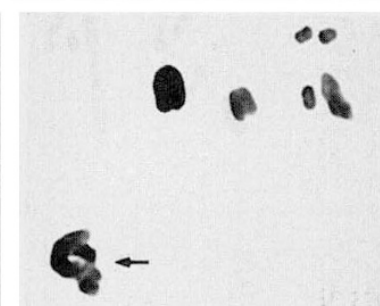

(g)

Fig. 5 Consequences of orientation behaviour of multiples in $D$. pratensis.

(a) Balanced segregation of ' 5612 ',

(b) balanced segregation of ' 561 ',

(c) abnormal AI segregation of '5612',

(b) balanced segregation of ' 561 ',

(c) abnormal AI segregation of '561'; note that centromere of 5.6 metacentric faces the pole to which the telocentric 5 has already migrated, (d) two lagging univalents in an AI of a '612' hybrid, (e) laggard chromosome 5 of quadrivalent ' 561 ', (f) laggard chromosomes of quadrivalent ' 561 ' (possibly 1.6 and 1 , arrow), (g) two macrospermatids and two normal spermatids. Bar $=10 \mu \mathrm{m}$.

isolation and the meiotic behaviour of complex multivalents. Chromosomal differences between taxa have long been recognized but the role of chromosomal rearrangements in evolution is controversial. Opinions range from an almost total rejection of any role for the chromosome to the more extreme positions that have been put forward by Matthey, 1966; White, 1968, 1969, 1970, 1973, 1975, 1978b, 1982; Mayr, 1970, 1982; Bush, 1975; Bush et al., 1977; Bickham \& Baker, 1979; Hewitt, 1979, 1985; John, 1981, 1983; Templeton, 1981; King, 1982, 1985, 1987; Patton \& Sherwood, 1983; Reig, 1984; Camacho, 1985; Lande, 1985; Baker \& Bickham, 1986; Sites \& Moritz, 1987; Bidau, 1988, 1990; Nachman \& Myers, 1989. Some biologists, however, have maintained a judicious and critical view by analysing available data in an impartial way (John, 1981; Patton \& Sherwood, 1983; King, 1987; Sites \& Moritz, 1987).

It seems that, amongst others, three problems have contributed to the present status of the subject. First, considerable effort has been devoted to the possibility of fixation of a given rearrangement or set of rearrangements in the light of current population genetics theory (Lande, 1985), which has led some authors to consider chromosomal speciation to be impossible (Nei et al., 1983; Templeton, 1981). However, interspecies chromosomal differences do exist and fixation might not always be necessary to establish postmating barriers between karyotypically divergent populations (Bidau, 1988).

Second, generalizations have been made, e.g. White's $(1968,1978)$ stasipatric model was proposed for the Australian Morabinae, but its extension to other organisms is debatable. Furthermore, different rearrangements have sometimes been treated as a single category regardless of their distinct genetic and cytological properties. In addition, when discussing the role of structural heterozygosity, spontaneous, polymorphic and polytypic conditions are frequently confused.

Third, the meiotic behaviour of hybrids between chromosomally divergent forms has not always been 

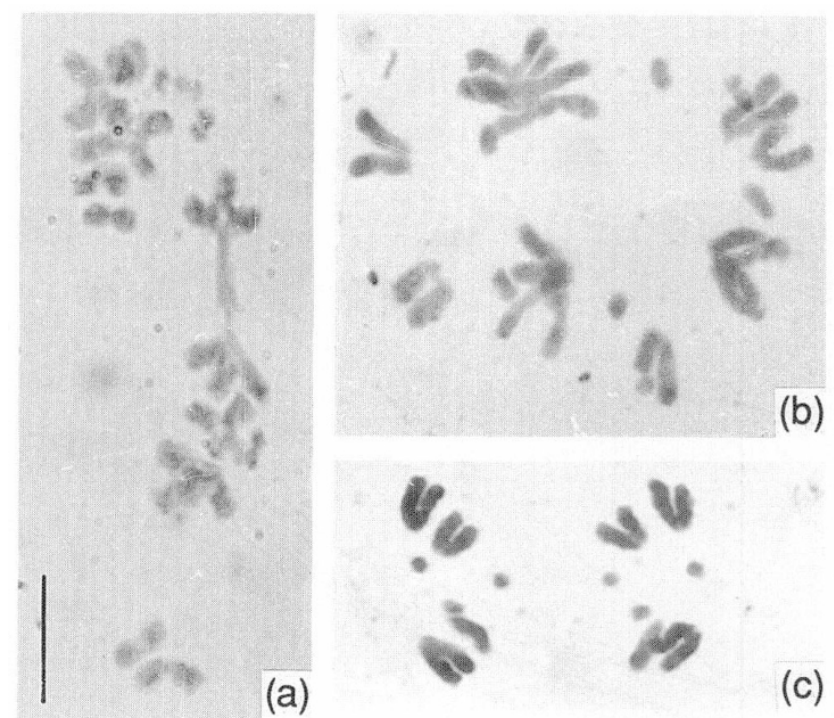

(a)
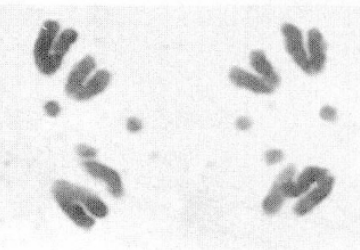

(c)

Fig. 6 Consequence of abnormal orientation and segregation of multivalents in D. pratensis. (a) Euploid sister MII showing remnant disjunction failure of two MI metacentrics possibly from the ' 561 ' quadrivalent, (b) diploid MII of ' 561 ' hybrid homozygous for the 3/4 fusion, (c) A neuploid AII of a '561' hybrid also homozygous for the $3 / 4$ fusion: note that three metacentrics and a telocentric (the $\mathrm{X}$ ) are present.

Bar $=10 \mu \mathrm{m}$.

Table 6 Frequencies of normal (haploid) and macrospermatids (diploid-polyploid) in 15 hybrids of Dichroplus pratensis and 15 randomly chosen non-hybrid males (data from the latter were pooled)

\begin{tabular}{ccll}
$\begin{array}{llll}\text { Hybrid } \\
\text { number }\end{array}$ & $\begin{array}{l}\text { Total } \\
\text { spermatids }\end{array}$ & $\begin{array}{l}\text { Haploid } \\
(\%)\end{array}$ & $\begin{array}{l}\text { Macrospermatids } \\
(\%)\end{array}$ \\
\hline Hybrids & & & \\
86308 & 2637 & 96.36 & 3.64 \\
86295 & 2651 & 96.38 & 3.62 \\
86214 & 1823 & 91.77 & 8.23 \\
83403 & 2142 & 95.84 & 4.16 \\
83398 & 2408 & 88.70 & 11.30 \\
83357 & 2604 & 98.46 & 1.54 \\
86210 & 2197 & 97.18 & 2.82 \\
86108 & 2210 & 96.43 & 3.57 \\
86117 & 1790 & 95.70 & 4.30 \\
86111 & 793 & 97.86 & 2.14 \\
83376 & 497 & 95.57 & 4.43 \\
83378 & 183 & 92.90 & 7.10 \\
83391 & 500 & 90.60 & 9.40 \\
83413 & 448 & 95.98 & 4.02 \\
83408 & 303 & 98.68 & 1.32 \\
Totals & 23186 & 95.30 & 4.70 \\
Non-hybrids & 15460 & 98.51 & 1.42 \\
\hline
\end{tabular}

Contingency $\chi^{2}=284.83 ; \mathrm{df}=1 ; P<0.001$.

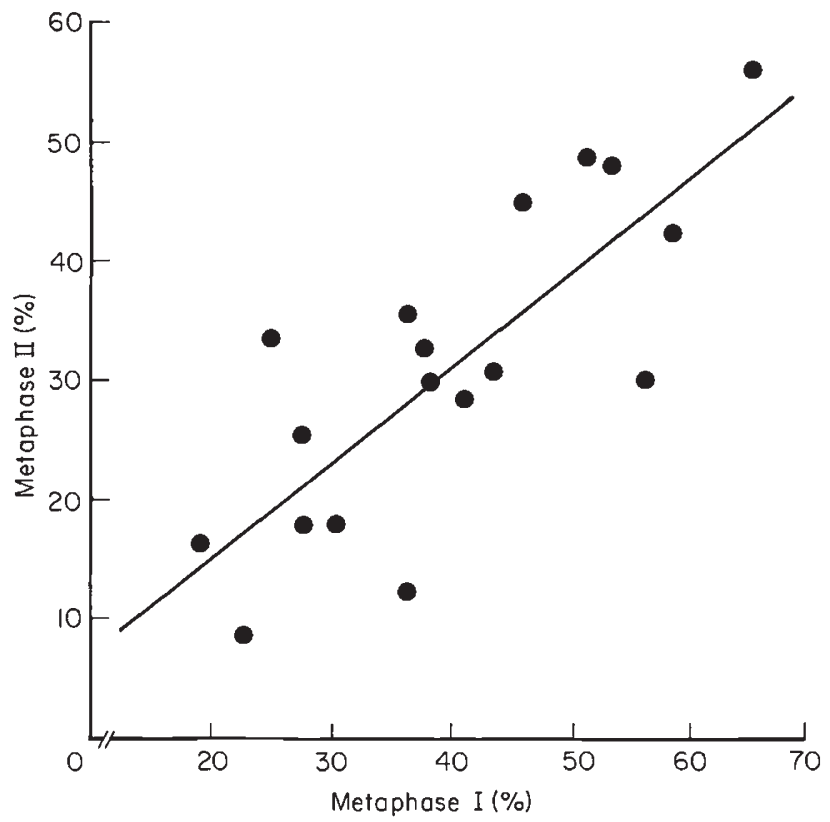

Fig. 7 The relationship between the frequency of abnormal first metaphases and abnormal second spermatocytes. See text and Table 2 for details.

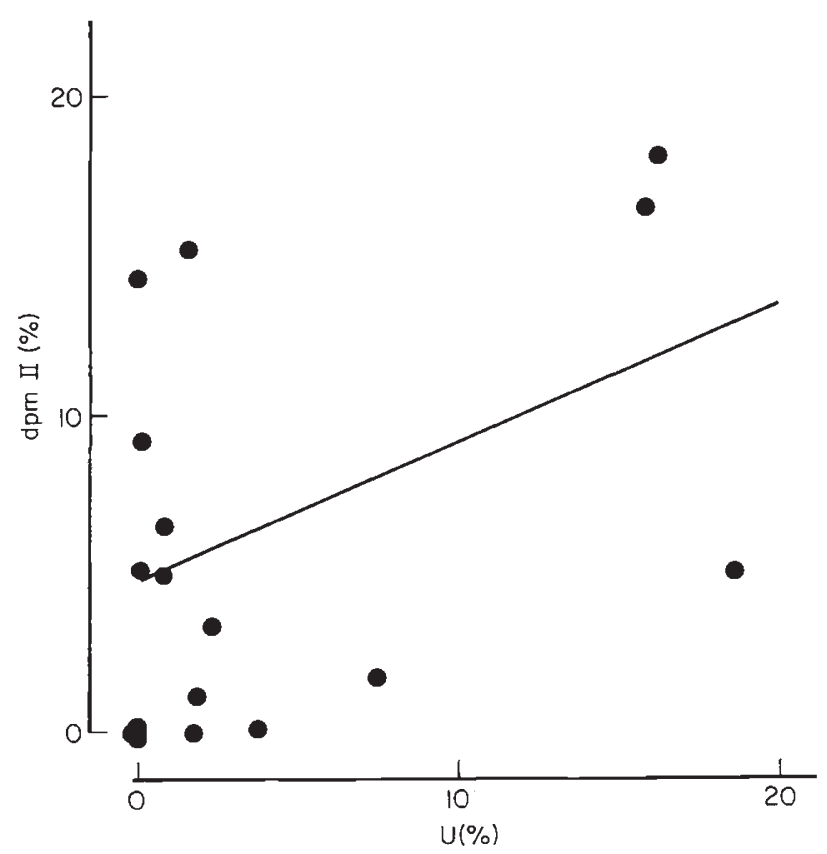

Fig. 8 The relationship between frequency of chiasma failure in multivalents $(U)$ at MI and diploid-polyploid second spermatocytes (dpMII). See text and Table 2 for details.

analysed although its importance has been emphasized (John, 1981, 1983; Sites \& Moritz, 1987). Robertsonian translocations are a major source of differentiation between taxa and have been thoroughly studied in 
mammals and grasshoppers although their role as postmating barriers to gene flow is debatable. Some authors attach great importance to them (Capanna, 1982; White, 1978b) but others have challenged this (Baker \& Bickham, 1986; Sites \& Moritz, 1987; Searle, 1988). The ability of a fusion to generate reproductive isolation depends on the chromosomes involved and their meiotic behaviour in the heterozygotes (Ford \& Evans, 1973; Bidau \& Mirol, 1988). If segregation of the trivalent is anomalous due to assymmetry or extensive proximal-interstitial chiasma formation, fertility will be reduced. The behaviour of fusion trivalents is, however, rather unpredictable (Bidau \& Mirol, 1988).

The latter is true of spontaneous fusions of grasshoppers (Hewitt, 1979) where non-alternate orientation can be as high as $97 \%$ [in a laboratory-reared mutant of Atractomorpha similis (Peters, 1982)] or $77 \%$ [in a natural germline mutant of Sinipta dalmani (M. I. Remis, personal communication)] and as low as $42 \%$ in Myrmeleotettix maculatus (Southern, 1967). In Mus however, Gropp \& Winking (1981) demonstrated very low frequencies of unbalanced segregation in single fusion heterozygotes. In balanced polymorphic systems, trivalent segregation is regular as in the common shrew (Searle, 1986b, 1988) and three grasshoppers including D. pratensis (Hewitt \& Schroeter, 1968; Hewitt, 1979; Bidau \& Hasson, 1984; Colombo, 1987; Bidau \& Mirol, 1988).

In $D$. pratensis, all seven polymorphic fusions have low levels of non-alternate orientation when heterozygous and lower frequencies of abnormal second spermatocytes (from 0 in most single heterozygotes to a maximum of $8.2 \%$ in a single male). Double and triple heterozygotes also have low percentages of abnormal second spermatocytes (Bidau \& Mirol, 1988). This situation is to be expected as fusions that give high sterility could not survive, hence could not become polymorphic.

Hybridization studies are also conflicting. Mouse hybrids between laboratory stocks and natural populations, heterozygous for single fusions, show heterogeneity in trivalent segregation (Gropp \& Winking, 1981). The sex trivalent of female hybrids of Podisma pedestris segregates efficiently (Barton, 1980). In contrast, natural hybrids between two Trimerotropis species that differ for a fusion, show a high incidence of aberrant meiotic behaviour (John et al., 1983).

When hybridizing forms differ for more than one fusion, a higher percentage of unbalanced gametes is expected due to the cumulative effects of each independent trivalent as in the coleopteran Chilocorus (Smith, 1966; Smith \& Virkki, 1978) and the rodent Ellobius talpinus (Bogdanov et al., 1986).

Several chromosomal speciation models have been

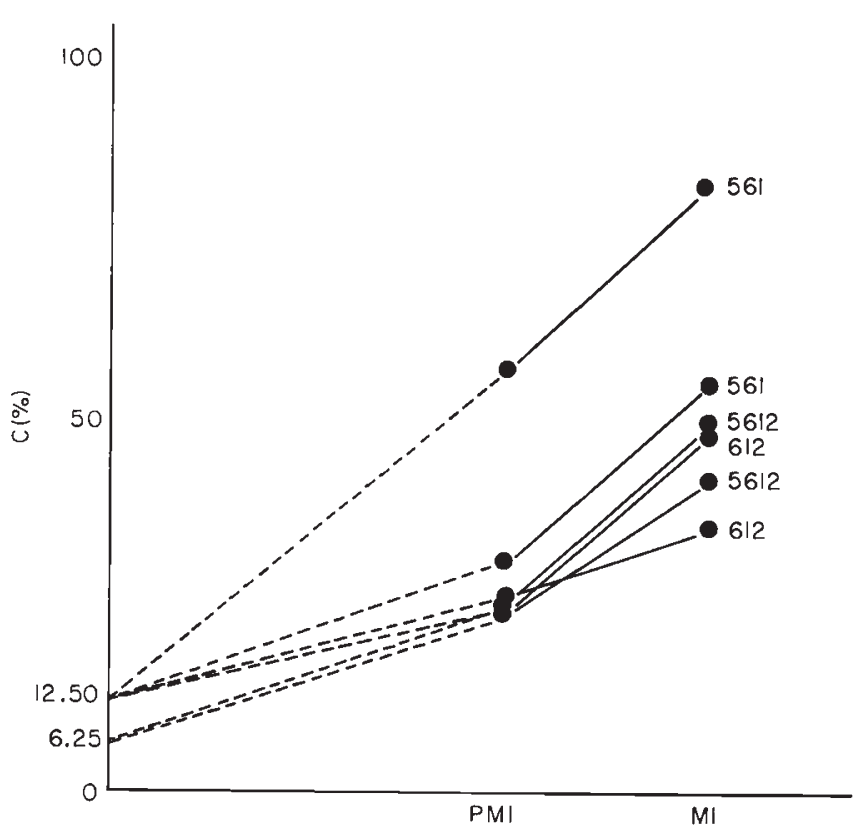

Fig. 9 Frequencies of alternate orientation at a hypothetical initial stage, prometaphase I (PMI) and metaphase (MI) in six hybrids of Dichroplus pratensis.

proposed (King, 1987; Sites \& Moritz, 1987) and some rest upon differences for single rearrangements (White, 1968, 1982; King, 1981) while others, rest upon for multiple ones (Hall, 1983; White, 1978b). Robertsonian variation is readily identifiable and therefore received special attention in this respect (John \& Hewitt, 1968; John \& Freeman, 1975; John, 1981, 1983; Searle, 1988). The importance of a type of Robertsonian variation, little considered in previous models, has been recently stressed. Such a model applies when karyotypically distinct populations differ in centric fusions with monobrachial homologies and it is based on observations pertaining to rodents, insectivores, bats, lizards and grasshoppers (Capanna, 1982; Moritz, 1983; Bidau, 1984, 1988; Capanna et al., 1985; Baker \& Bickham, 1986; Searle, 1986a, 1988; Sites \& Moritz, 1987). The result of hybridization between taxa, with monobrachial homologies, is the formation of higher order Robertsonian multivalents Capanna et al., 1976; Gropp \& Winking, 1981; Capanna, 1982; Redi \& Capanna, 1988) that orientate non-alternately at frequencies much higher than those expected from the combined probabilities of independent fusions (see below).

It is interesting to analyse the meiotic behaviour of $D$. pratensis hybrids in relation to this model, not because chromosomal speciation is effectively occurring in this case (certainly, introgression happens) but because this intermediate situation could shed light on the problem. Several points are worth discussing. First, 
the frequency of non-alternate $\mathrm{MI}$ orientation is heterogeneous but invariably high. In all hybrids the total frequency of abnormal MI cells is significantly higher than the combined frequencies of the independent heterozygous fusions. From data of the parental populations, the theoretical combined frequencies of abnormal behaviour of the 1-1.6-6 and 5-5.6-6 trivalents is $12.07 \%$ while the actual lowest frequency for a ' 561 ' hybrid is $18.5 \%$. The same is true for fusions $1 / 2$ and $1 / 6(25.10 \%)$ and $1 / 2,1 / 6$ and $5 / 6(25.42 \%)$ as compared with the ' 612 ' and ' 5612 ' hybrids $(50-60 \%)$ (see Table 2). A strong interaction component thus seems to operate between fusions when combined in a multivalent.

Second, heterogeneity probably reflects the effect of the genetic background upon multivalent behaviour, considering that some structural hybrids may be introgressants. The effect of genetic background upon multivalent behaviour has been well documented in cockroaches (John, 1983).

Third, and most relevant, is the fact that behaviour of multivalents in this species is probably conditioned by the polymorphic status of the involved fusions, adapted to alternate orientation and balanced segregation (Bidau \& Mirol, 1988). Since polymorphic fusions of $D$. pratensis produce an elimination of proximal chiasmata in the involved chromosomes (Bidau, 1990), trivalents attain high levels of alternate orientation. Thus multivalents could be preadapted and frequencies of non-alternte orientation are lower than the maximum expected if chiasma distribution was nonrestricted (however, see below).

The latter could explain why reorientation leading to alternate orientation occurs between PMI and MI. Further reorientation probably occurs at late MI, since almost invariably, abnormal second spermatocytes exist at frequencies lower than those of abnormal first metaphases. The discrepancy between MI orientation and AI segregation could be also due to the analysis of different cell populations (Sybenga \& Rickards, 1987). In $D$. pratensis, however, it is evident that, despite the multivalent and male involved, abnormal second spermatocytes are almost invariably less than expected from non-alternate MI orientation, which also occurs in trivalents of this species (Bidau \& Mirol, 1988). This suggests that reorientation towards alternate configurations occurs effectively even at late MI, which is not surprising since Church \& Lin (1985) showed that in Drosophila spermatocytes, bivalents can reorient up to $10 \mathrm{~min}$ before AI (see also Nicklas, 1985 and Nicklas \& Kubai, 1985). An alternative possibility (although not supported by factual evidence) is that aneuploid cells are eliminated during intekinesis.

Nevertheless, quadrivalents and quinquivalents show much higher frequencies of non-alternate orientation than single and multiple heterozygotes (compare results in this paper with those of Bidau \& Mirol, 1988). These frequencies are comparable to those of quadrivalents formed in spontaneous reciprocal translocation mutants (John, 1987) which are assumed to be unable to produce a stable polymorphism because of abnormal segregation. In addition, frequencies of abnormal second spermatocytes are high, which implies a severe reduction in fertility resulting from aneuploidy and the formation of macrospermatids (Bidau \& Confalonieri, 1988), which seem not to develop into functional spermatozoa (John, 1983). The origin of macrospermatids is not directly related to univalence at MI, which suggests that lagging of univalents resulting from chiasma failure and segregation of linear multivalents, or the lack of resolution of linearly oriented multiples, causes suppression of cytokinesis.

It is important to consider the results that could be obtained if the monobrachial fusions are fixed or polymorphic in the interacting taxa. Clearly, in multivalentforming hybrids, the only functional gametes will be those that regenerate the parental karyotypes. If the fusions are fixed all hybrids will form multivalents and, even if they are partially fertile, will produce hybrid or parental offspring when they cross with any type of individual within the contact zone. Thus, the integrity of the karyotypic forms will be preserved and gene flow will be determined in principle by the hybrids' fertility.

If the hybridizing populations are polymorphic for monobrachial fusions then not all hybrids will be so structurally and there should be over the generations, an increase in standard (telocentric) karyotypes which might be favoured since these individuals are the only ones that cannot produce complex hybrid offspring irrespective of the karyotype of the individuals with which they mate. This situation is found by Searle (1986a) in a hybrid zone between chromosomal races of Sorex araneus in England. This is not, however, the situation in the $D$. pratensis' hybrid zone at Sierra de la Ventana where, on the contrary, standard karyotypes or basic homozygotic karyotypes for any telocentric combination are the rarest. In fact, most population frequencies of metacentrics are very high (C. J. Bidau $e t$ al., unpublished results).

The latter has meaning when the model put forward to explain the maintenance of fusion polymorphisms in the species is considered (Bidau, 1988, 1990; Bidau et al., 1989). According to this model, the polymorphisms of different races are maintained to preserve different sets of adaptive heterotic supergenes and this is achieved through the reduction in recombination produced by the fusions (Bidau, 1988, 1990). 
This means, however, that weak selection occurs and hence linkage disequilibium between epistatic loci which have been joined by the fusions is a likely complementary mechanism since elimination of crossing-over in pericentric regions would preserve this tight linkage. Thus, standard karyotypes, although producing no hybrid offspring could be less adaptive because of the lack of linkage between those epistatic loci. This suggests that in this case the parental fusions karyotypes could be favoured by selection leading, if not to fixation, to the maintenance of high frequencies of metacentrics. In fact, local fixation of three fusions has been observed in at least one semi-isolated population (Tosto, 1989; Bidau et al., 1990). Furthermore, this implies that hybrids could be adaptively inferior not only because of reduced fertility but because they could also produce recombinant offspring that would be ill-adapted [in fact, a pronounced modification of the expected chiasma patterns occurs in multivalents (C. Y. Bidau and Fenocchio, in preparation). A situation of this kind could favour the development of premating isolation.

Although the situation in $D$. pratensis is difficult to interpret as the hybrid zones have not yet been clearly delimited, it is certain that some degree of postzygotic isolation exists. Studies intended to solve these problems are in progress.

\section{Acknowledgements}

I wish to express my sincere gratitude to Dr Cristina D'Aiutolo and my sons, Claudio Jr and Pablo, for help in the collection and processing of grasshoppers. I am also indebted to Professor Dr J. Sybenga and Professor Dr Osvaldo Reig for critical reading of the original typescript and useful comments. Suggestions by an anonymous reviewer improved the text substantially. I would also like to thank my former students and friends Miss Daniela Tosto and Miss Patricial Mirol, for patient work and comments and of course to Miss Mabel Giménez for encouragement and excellent company.

This work was supported by grants from CONICET and Universidad de Buenos Aires.

\section{References}

BAKER, R. J. AND BICKHAM, J. W. 1986. Speciation by monobrachial centric fusions. Proc. Natl. Acad. Sci., USA, 83, 8245-8248.

BARTON, N. H. 1980. The fitness of hybrids between two chromosomal races of the grasshopper Podisma pedestris. Heredity, 45, 47-59.

BARTON, N. H. AND HEWITT, G. M. 1981. Hybrid zones and speciation. In: Atchley, W. R. and Woodruff, D. S. Essays on Evolution and Speciation in Honour of M.J. D. White, Cambridge University Press, Cambridge, pp. 109-145.

barton, n. H. And hewitT, G. M. 1985. Hybrid zones. Ann. Rev. Ecol. Syst., 16, 113-148.

BARTON, N. H. AND HEWITT, G. M. 1989. Adaptation, speciation and hybrid zones. Nature, 341, 497-503.

BICKHAM, J. W. AND BAKER, R. J. 1979. Canalization model of chromosomal evolution. In: Schwartz, J. H. and Rollins, H. G. (eds), Models and Methodologies in Evolutionary Theory, Bull. Carnegie Mus. Nat. Hist., 13, 70-84.

BIDAU, C. J. 1984. Ph.D. Thesis, Universidad de Buenos Aires.

BIDAU, C. J. 1986. Geographic distribution of chromosome polymorphisms in Dichroplus pratensis Bruner (Melanoplinae, Acrididae) in Argentina. Proceedings of the 4th Triennial Meeting, Pan American Acridol Society, Ann Arbor, 165-166.

BIDAU, C. J. 1988. Zonas híbridas en Ortópteros: el ejemplo de Dichroplus pratensis (Acrididae). Rev. Soc. Entomol. Argentina (in press).

BIDAU, C. J. 1989. The complex Robertsonian system of Dichroplus pratensis (Melanoplinae, Acrididae). II. Effects of the fusion polymorphisms on chiasma frequency and distribution Heredity (in press).

BIDAU, C. J. AND CONFALONIERI, V. A. 1988. A cytophotometric study of micro- and macrospermatids in three species of grasshopper (Acrididae). Cytobios, 53, 31-41.

BIDAU, C. J. AND HASSON, E. R. 1984. Population cytology of Leptysma argentina Bruner (Leptysminae, Acrididae). Genetica, 62, 161-175.

BIDAU, C. J. AND MIROL, P. 1988. Orientation and segregation of Robertsonian trivalents in Dichroplus pratensis (Acrididae). Genome, 30, 947-958.

BOGDANOV, Y. F., KOLOMIETS, O. L., LYAPUNOVA, E. A., YANINA, I. Y AND MAZURova, T. F. 1986. Synaptonemal complexes and chromosome chains in the rodent Ellobius talpinus heterozygous for ten Robertsonian translocations. Chromosoma, 94, 94-102.

BUSH, G. L. 1975. Modes of animal speciation. Ann. Rev. Ecol. Syst., 6, 339-364.

BUSH, G. L., CASE, S. M., WILSON, A. C. AND PATTON, J. L. 1977. Rapid speciation and chromosomal evolution in mammals. Proc. Natl. Acad. Sci. USA, 74, 3942-3946.

CAMACHO, J. P. M. 1985. Las reordenaciones cromosómicas en la evolución de los sistemas genéticos de Ortópteros. In: Gosálvez, J. López-Fernández, C. and García de la Vega, C. (eds.), Orthoptera. Vol. 1, Fundación Ramón Areces, Madrid, pp. 114-136.

CAPANNA, E. 1982. Robertsonian numerical variation in animal speciation: Mus musculus, an emblematic model. In: Barigozzi, C. (ed.), Mechanisms of Speciation, Alan R. Liss, New York, pp. 155-177.

CAPANNA, E., CORTI, M., NASCETTI, G. AND BUllini, L. 1985. Preand post-mating isolating mechanisms in the speciation of the European long-tailed house mouse Mus musculus domesticus. Acta Zool. Fennica, 170, 115-120.

соцомво, Р. с. 1987. Effect of centric fusions on chiasma frequency and position in Leptysma argentina. I. Spontaneous and stable polymorphic centric fusions. Genetica, 72, 171-179. 
CHURCH, K. AND LIN, H.-P. P. 1985. Kinetochore microtubules and chromosome movement during prometaphase in Drosophila melanogaster spermatocytes studied in life and with the electron microscope. Chromosoma, 92, 273-282.

FORD, C. E. AND EVANS, E. P. 1973. Robertsonian translocation in mice: segregational irregularities and zygotic unbalance. Chromosomes Today, 4, 387-397.

GROPP, A. AND WINKING, H. 1981. Robertsonian translocations: cytology, meiosis, segregation pattern and biological consequences of heterozygosity. Symp. Zool. Soc. Lond., 47, 141-181.

HALL, W. P. 1983. Modes of speciation and evolution in the sceloporine iguanid lizards. Epistemology of the comparative approach and introduction to the problem. In: Rhodin, A. G. J. and Miyata, K. (eds) Advances in Herpetology and Evolutionary Biology, Mus. Comp. Zool., Harvard University Press, Cambridge, 643-679.

HEWIT, G. M. 1979. Orthoptera. In: John, B. (ed.) Animal Cytogenetics 3. Insecta 1, Gebruder Borntraeger, BerlinStuttgart.

HEWITT, G. M. 1985. The structure and maintenance of a hybrid zone. In Gosálvez, J. López-Fernández, C. and García de la Vega (eds) Orthoptera. Vol. 1. Fundación Ramón Areces, Madrid, pp. 15-54.

HEWITT, G. M. 1988. Hybrid zones-Natural laboratories for evolutionary studies. TREE, 3 (7), 158-167.

HEWITT, G. M. AND SCHROETER, G. L. 1968. Population cytology of Oedaleonotus. I. The karyotypic facies of Oedaleonotus enigma. Chromosoma, 25, 121-140.

JoHN, B. 1981. Chromosome change and evolutionary change: a critique. In: Atchley, W. R. and Woodruff, D. S. (eds) Evolution and Speciation, Cambridge University Press, Cambridge, pp. 23-51.

JoHN, B. 1983. The role of chromosome change in the evolution of Orthopteroid insects. In: , A. K. and Sharma, A. S. (eds) Chromosomes in the Evolution of Eukaryotes, CRC Press, Boca Ratón, pp. 1-110.

JoHN, B. 1987. The orientation behavior of multiple chromosome configurations in Acridid grasshoppers. Genome, 29, 292-308.

JOHN, B. AND FREEMAN, M. G. S. 1975. Causes and consequences of Robertsonian exchange. Chromosoma, 52, 123-136.

JOHN, B AND HEWTT, G. M. 1968. Patterns of chromosome evolution within the Orthoptera. Chromosoma, 25, 40-74.

JOHN, B. AND LEWIS, K. R. 1965. The Meiotic System. SpringerVerlag, New York.

JOHN, B., LIGHTFOOT, D. C. AND WEISSMAN, D. B. 1983. The meiotic behavior of natural $F_{1}$ hybrids between Trimerotropis suffusa Scudder and T. cyaneipennis Benner (Orthoptera: Oedipodinae). Can. J. Genet. Cytol., 25, 467-477.

KING, M. 1981. Chromosome change and speciation in lizards. In: Atchley, W. R. and Woodruff, D. S. (eds) Essays on Evolution and Speciation in Honour of M. J. D. White. Cambridge University Press, Cambridge, pp. 262-285.

KING, M. 1982. A case for simultaneous multiple rearrangements. Genetica, 59, 53-60.

KING, M. 1985. The canalization model of chromosomal evolution: a critique. Syst. Zool., 34, 69-75.

KING, M. 1987. Chromosomal rearrangements, speciation and the theoretical approach. Syst. Zool., 34, 69-75.

KING, M. 1987. Chromosomal rearrangements, speciation and the theoretical approach. Heredity, 59, 1-6.

LANDE, R. 1985. The fixation of chromosomal rearrangements in a subdivided population with local extinction and colonization. Heredity, 54, 323-332.

MATTHEY, R. 1966. Le polymorphisme chromosomique des Mus africains du sousgenre Leggada. Rev. Suisse Zool., 73, 585-607.

MAYR, E. 1970. Populations, Species and Evolution, Harvard University Press, Cambridge.

MAYR, E. 1982. Processes of speciation in animals. In: Barigozzi, C. (ed.) Mechanisms of Speciation, Alan R. Liss, New York, pp. 1-19.

MIROL, P., TOSTO, D. AND BIDAU, C. J. 1988. Variaciones abruptas en frecuencias cromosómicas en una zona híbrida. $X I X$ Congr. Argent. Genet. (Jujuy), 89.

MORITZ, C. 1986. The population biology of Gehyra (Gekkonidae): Chromosome change and speciation. Syst. Zool., 35, 46-67.

NEI, M., MARUYAMA, T. AND wU, C. 1983. Models of evolution of reproductive isolation. Genetics, 103, 557-579.

NICKLAS, R. B. 1985. Mitosis in eukaryotic cells: an overview of chromosome distribution. In: Dellarco, V. L., Voytek, P. E. and Hollaender, A. (eds) Aneuploidy, Plenum Press, New York, pp. 183-195.

NICKLAS, R. B. AND KUBAI, D. F. 1985. Microtubules, chromosome movement and reorientation after chromosomes are detached from the spindle by micromanipulation. Chromosoma, 92, 313-324.

PATTON, J. L. AND SHERwOod, s. w. 1983. Chromosome evolution and speciation in rodents. Ann. Rev. Ecol. Syst., 14, 139-158.

PETERS, G. B. 1982. The recurrence of chromosome fusion in inter-population hybrids of the grasshopper Atractomorpha similis. Chromosoma, 85, 323-347.

REDI, C. AND CAPANNA, E. 1988. Robertsonian heterozygotes in the house mouse and the fate of their germ cells. In: Daniel, A. (ed.) The Cytogenetics of Mammalian, Alan R. Liss, New York, 315-319.

REIG, O. A. 1984. Significado de nos métodos citogenéticos para la distinción y la interpretación de las especies, con especial referencía a los mamíferos. Rev. Mus. Arg. Cs. Nat., 13 (3), 19-44.

SEARLE, J. B. 1986a. Factors responsible for karyotypic polymorphism in the common shrew, Sorex araneus. Proc. $R$. Soc. Lond., B229, 277-292.

SEARLE. J. B. 1986b. Meiotic studies of Robertsonian heterozygotes from natural populations of the common shrew. Cytogenet. Cell Genet., 41, 154-162.

SEARLE, J. B. 1988. Selection and Robertsonian variation in nature: the case of the common shrew. In: Daniel, A. (ed.) The Cytogenetics of Mammalian Autosomal Rearrangements, Alan R. Liss, New York, pp. 507-531.

SITES, J. W. AND MORITZ, C. 1987. Chromosomal evolution and speciation revisited. Syst. Zool., 36 (2), 153-174.

SMITH, s. G, 1966. Natural hybridization in the coccinellid 
genus Chilocorus. Chromosoma, 18, 380-406.

SMITH, s. G. AND VIRKKI, N. 1978. Coleoptera. In: John, B. (ed.) Animal Cytogenetics 3. Insecta 5, Gebruder Borntraeger, Berlin.

SyBenga, J. 1975. Meiotic Configurations. Springer-Verlag. Berlin.

SYBENGA, J. AND RICKARDS, G. K. 1987. The orientation of multivalents at meiotic metaphase I: a workshop report. Genome, 29, 612-620.

TEMPLETON, A. R. 1981. Mechanisms of speciation - a population genetic approach. Ann. Rev. Ecol. Syst., 12, 23-48.

WHITE, M. J. D. 1968. Models of speciation. Science, 159, 1065-1070.

WHITE, M. J. D. 1969. Chromosomal rearrangements and speciation in animals. Ann. Rev. Genet., 3, 75-98. white, M. J. D. 1970. Cytogenetics of speciation. J. Aust. Entomol. Soc., 9, 1-6.

white, M. J. D. 1973. Animal Cytology and Evolution. 3rd edn. Cambridge University Press, London.

WHITE, M. J. D. 1975. Chromosomal repatterning: regularities and restrictions. Genetics, 79, 63-72.

white, M. J. D. 1978a. Modes of Speciation. W. H. Freeman, San Francisco.

WHITE, M. J. D. $1978 \mathrm{~b}$. Chain processes in chromosomal speciation. Syst. Zool., 27, 285-298.

WHITE, M. J. D. 1982. Rectangularity, speciation and chromosome architecture. In: Barigozzi, C. (ed.) Mechanisms of Speciation, Alan R. Liss, New York, pp. 75-103. 